\title{
Barriers and challenges for primary care service in the COVID- 19 pandemic
}

\author{
Dela Erjalia $^{1}$, Rizma Adlia Syakurah ${ }^{2}$ \\ ${ }^{1}$ Medical Doctor Profession Study Program, Faculty of Medicine, Sriwijaya University, Indonesia \\ ${ }^{2}$ Public Health Faculty, Sriwijaya University, Indonesia
}

\begin{tabular}{l} 
Article Info \\
\hline Article history: \\
Received Nov 20, 2020 \\
Revised May 11, 2021 \\
Accepted Jun 16, 2021 \\
\hline
\end{tabular}

Keywords:

Barriers and challenges

COVID-19

General practitioners

Primary care

\begin{abstract}
The COVID-19 pandemic is such a barrier for health systems around the world including Indonesia. Primary care is the first-line in controlling the pandemic at the community level, but there are many barriers and challenges faced by doctors during the service that are not fully recognized. This aimed to distinguish barriers and challenges in health centers and/clinics amid the COVID-19 widespread. This was qualitative study with a phenomenological approach. As much 44 health centers/clinical specialists interviewed in October 2020. Then, the data categorization method/coding and content analysis used. There were three themes related to the barriers and challenges confronted by specialists in health centers/clinics, specifically barriers and challenges based on service management, environment, and individuals. The barriers and challenges confronted are related to changes within the consultation flow, a diminished number of patient visits, limited supplies of personal protective equipment (PPE), patient states of mind and behavior within the confront of a pandemic, and progressively heavier burdens and duties for doctors. It is necessary to provide specific, valid, and right-ontarget knowledge in improving community behavior in efforts to prevent COVID-19 infection and the government's important role to be more concerned about the future of health workers.
\end{abstract}

This is an open access article under the CC BY-SA license.

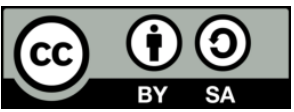

\section{Corresponding Author:}

Rizma Adlia Syakurah

Public Health Faculty

Sriwijaya University

J1. Raya Palembang-Prabumulih KM. 32 Indralaya, Ogan Ilir, South Sumatera, 30662, Indonesia

Email: rizma.syakurah@gmail.com

\section{INTRODUCTION}

On March 11, 2020 World Health Organization (WHO) has declared that corona virus is a global pandemic [1]. Coronaviruses (CoV) is the main cause of COVID-19 disease which is only discovered in 2019 in the province of Wuhan, China [2]. The status of a global pandemic that has been established by WHO indicates that the spread of COVID-19 moves fastly that almost no country in the world can ensure that it is protected from the corona virus [2]. In Indonesia, firstly, COVID-19 cases recorded on March 2, 2020 and reached 353,461 confirmed cases with 12,347 deaths as of October 17, 2020 [3]-[5]

COVID-19 pandemic is such a barrier for health systems around the world including Indonesia. Primary care is the first-line in controlling the pandemic at the community level, but many barriers and challenges faced by doctors during the service process are not fully recognized [6]. Rapid increase of the need of care for people with COVID-19 is exacerbated by fear, misinformation, and restrictions of people movement and supplies that interfere with the delivery of front-line healthcare for everyone. If a pandemic situation requires a change in workload, then all healthcare workers have to work carefully and be supported 
with adequate resources, in this case what is meant is special training for medical personnel and an adequate supply of personal protective equipment. Besides, due to the copious focus attention on COVID-19, several priority programs were blocked and even disabled [7].

COVID-19 pandemic has sparked concerns of infection prevention and control for the practice and work behavior of healthcare workers. For example, the consistent used of personal protective equipment (PPE) can reduce the risk of infection in healthcare workers. However, the availability of PPE may not be supportive [8]. By identifying the barriers and challenges occurred in preventing and controlling COVID-19 pandemic, researchers aim to describe of the barriers faced by medical personnel, especially doctors in primary care who have an important role as forefront in controlling and preventing COVID-19 pandemic. Therefore, it will be easier to identify strategies that will support healthcare workers to carry out COVID-19 pandemic.

\section{RESEARCH METHOD}

In this qualitative research, the type of research used is descriptive research with a phenomenological approach. This study aims to identify barriers and challenges at health centers and/clinics during the COVID-19 pandemic. The test of this inquire about is practicing specialists in primary services who were interviewed by students of the 2017 Sriwijaya University medical faculty. The witnesses were chosen based on purposive testing who met the following criteria: i) Doctors who worked in primary services amid the COVID-19 pandemic, ii) Health facilities affected during the COVID-19 pandemic. The overall number of respondents in this study were 44 doctors who practiced at the health centers/clinic.

This research is a qualitative research which is comprised of steps to classify and clarify the data gotten from in-depth interviews. Interviews were conducted in October 2020 through long-distance communication media, specifically in Zoom and WhatsApp to avoid transmission of COVID-19 during pandemic. Processing the results of in-depth interviews is gotten from the results of categorization/coding and content analysis carried out in a few stages, specifically: i) Collecting all results from in-depth interviews, ii) Making transcripts of the interview comes about, iii) Recognizing information obtained, iv) Re-reading the transcripts interview and make keywords, and v) Conducting the information determination agreeing to the chosen theme and compiled agreeing to three categories, specifically in service management, environment and individuals.

\section{RESULTS AND DISCUSSION}

Informant in this study was 44 individuals with an average age of 30.97 years, comprising 26 general practitioners, 15 internship doctors, two heads of Health centers and one non-permanent doctor. The entire number of respondents was 27 females and male respondents were 17. Based on the practice area, there were 32 Health centers doctors and 12 clinic doctors as shown in Table 1 (see in appendix). The three fundamental subjects were found related to the barriers and challenges that occurred in primary services amid the COVID-19 widespread, specifically in service management, environment, and individuals.

\subsection{Service management}

There are three issues that ended up barriers and challenges in service management. To begin with, the community finds it troublesome to carry out consultations due to restricted time and ways of communicating regarding the current widespread situation, which influences the diagnosis. Second, there is a change within the number of patient visits that has diminished, usually the effect of the pandemic which causes patients to be anxious to look for treatment straightforwardly. Third, implementing work programs is hampered because of the widespread situation, which makes it impossible to go directly to the field as presented in Table 2.

\subsubsection{Environment}

There are two issues that gotten to be barriers and challenges based on the environment. To begin with, amid the pandemic, the supply of PPE was exceptionally limited; this was since the PPE supply from the government did not have any result in an expanding required. Second, the facilities and infrastructure are still restricted so that the health protocol cannot be completely implemented as shown in Table 3 . 
Table 2. Interview results related to barriers and challenges based on service management

\begin{tabular}{|c|c|}
\hline Themes & Interpretations \\
\hline $\begin{array}{l}\text { Society difficulties in consulting during the } \\
\text { COVID-19 pandemic }\end{array}$ & $\begin{array}{l}\text { Physical examination and history are nonspecific and difficult to perform [9] } \\
\text { 1. Limited of time and action that hinder the process of anamnesis and physical } \\
\text { checking } \\
\text { 2. Poor internet access, so that online consultation is hampered } \\
\text { 3. Distance between doctor and patient make it difficult for doctors to interpret the } \\
\text { patient's complaints } \\
\text { Misperception related to communication [10] } \\
\text { 1. Language used in communication have to adapt to the patient's language } \\
\text { 2. Right word selection in order to make them understand } \\
\text { Difficulties and doubts in diagnosis [11] } \\
\text { 1. Anamnesis and physical checking data are incomplete } \\
\text { 2. Limited time in diagnosing, so that doctors do not have much time to diagnosing } \\
\text { the patient's complaints }\end{array}$ \\
\hline $\begin{array}{l}\text { The change of number of patient visits } \\
\text { during the COVID-19 pandemic }\end{array}$ & $\begin{array}{l}\text { Decreasing number of patient visits due to the pandemic [12] } \\
\text { 1. Patients feel afraid to go to the health centers directly } \\
\text { 2. Restriction number of visits due to the implementing of health protocols } \\
\text { 3. Patients prefer online consultation because they feel safer rather than come directly } \\
\text { to the health center }\end{array}$ \\
\hline $\begin{array}{l}\text { Barriers in implementing work programs } \\
\text { during the COVID-19 pandemic }\end{array}$ & $\begin{array}{l}\text { Implementation of work program is hampered that it does not reach the standards [10] } \\
\text { 1. Restriction to meet patients in person because of pandemic } \\
\text { 2. Delay and elimination of some work programs that are considered to be a risk in the } \\
\text { spread of the corona virus }\end{array}$ \\
\hline
\end{tabular}

Table 3. Interview results related to environmental barriers and challenges

\begin{tabular}{|c|c|}
\hline Themes & Interpretations \\
\hline \multirow{6}{*}{$\begin{array}{l}\text { The availability of PPE and its use } \\
\text { during the COVID- } 19 \text { pandemic }\end{array}$} & PPE supplies are exceptionally constrained and don't meet standards [13] \\
\hline & 1. The remote working area causes the distribution of PPE to be very limited \\
\hline & 2. Doctors save on the use of PPE and pay their own costs to meet PPE shortages \\
\hline & $\begin{array}{l}\text { 3. The availability of PPE provided by the government is very limited but its use continues to } \\
\text { increase. }\end{array}$ \\
\hline & The use of PPE that is ineffective makes doctors uncomfortable using it [14] \\
\hline & 1. Health facilities do not support \\
\hline \multirow{4}{*}{$\begin{array}{l}\text { Availability of facilities and } \\
\text { infrastructure for primary services } \\
\text { during the COVID-19 pandemic }\end{array}$} & 2. Doctors have to remove pairs of PPE so that the risk of being exposed to corona is very large \\
\hline & Limited facilities and infrastructure in primary services [13] \\
\hline & $\begin{array}{l}\text { 1. People in remote areas difficult to access the internet in order to conduct online } \\
\text { consultations, and health facilities are still limited and less comprehensive }\end{array}$ \\
\hline & $\begin{array}{l}\text { 2. Availability and development of infrastructure that is not maximized, so that does not yet } \\
\text { support communities to implement health protocols correctly }\end{array}$ \\
\hline
\end{tabular}

\subsubsection{Individual/personal}

From the results gotten, there are three issues that ended up barriers and challenges based on people/individual. To begin with, the psychological state and state of mind of the patient are related to the high level of anxiety and fear of the patient as a result of the pandemic circumstance. Second, the low level of education and the patient's economy make it troublesome to provide education. Usually due to the patient's low knowledge, so they are effortlessly impacted by scam information and distrust doctors. Third, the doctor's psychological condition gets to be irritated. This is because the burdens and duties confronted during the widespread are so overwhelming doctors feel on edge and stressed as shown in Table 4 (see in appendix).

According to WHO, Primary Health Care is an essential health service that held based on technology and practical procedures, in accordance with scientific principles and accepted by the society, which can be achieved by individuals and families in society by active role [5]. Primary health services will not be same in every region. This is due to differences in geographic and demographic conditions, regional and individual physical abilities, public health status and attention from local governments in health development on each region. From those several differences, those will be the focus of researchers to give further discuss about the barriers and challenges that occur in primary services during COVID-19 pandemic. Regarding to the previous research, researchers categorized barriers and challenges based on service management, environment, and individuals [16].

\subsubsection{Barriers and challenges based on management service}

According to Ministry of Health Republic Indonesia, management is a series of processes consisting of planning, organizing, implementing and controlling (Planning, Organizing, Actuating, and Controling) to achieve goals/objectives effectively and efficiently [17]. Another definition of management according to Luther Gullick is a field of science that attempts to systematically understand why and how humans work 
together to achieve goals [18]. Meanwhile, according to Daviddow and Utal, service can be defined as any business that enhances customer satisfaction [19].

When viewed from the opinion of experts, it can be concluded that service management is an effort that goes through a systematic process in achieving goals effectively and efficiently. Effective in this case means that the expected goals can be achieved through the implementation process which is carried out properly and correctly and with quality, based on the results of a situation analysis supported by data and accurate information (evidence based). Meanwhile, efficient means how the health care utilizes available resources to be able to carry out health efforts according to standards properly and correctly, so as to realize the performance targets that have been set. However, the current global pandemic situation has resulted in several health efforts being made unable to meet standards so that the predetermined performance targets cannot be achieved.

Based on the collected data from the results of interviews with doctors who served in primary care, they express about what are barriers and challenges in providing health services in a pandemic situation. One of the barriers and challenges that occur is the difficulty in consulting with patients, this case is related to the anamnesis and physical checking that cannot be done holistically and specifically. There are some factors that support in this case, limited time for consultation, and the implementation of social distancing, so that it is limited for doctors to perform anamnesis procedure and physical checking which one of the references becomes for a doctor in making a diagnosis.

The changes that occur are not only have an impact on the consultation but also on the implementation of existing work programs in primary services. Based on the answers taken from the interview data, the doctor said that in current pandemic situation, some work programs in primary services have been hampered, some even have to be stopped. In line with that, there is also a decrease in the number of patients visiting health centers and clinics. This is also caused by pandemic conditions that make it is impossible or even limited activities such as visits to residents' homes, schools and offices.

Based on the comparison of the results of this study with the Ministry of Health's regulation number 75 of 2014 concerning Community health centers, which states that health centers have the task of implementing health policies to achieve health development goals in their working areas and the function of organizing first-level Public Health Efforts (Upaya Kesehatan Masyarakat (UKM)) and Individual Health Efforts (Upaya Kesehatan Perseorangan $(U K P)$ ) in their working areas has not been fully fulfilled, this is based on the limited that made as a form of control of a pandemic condition that impact on service management [17].

Primary level of health facilities is gatekeepers in health services in the era of National Health Insurance, meaning that the authority to decide which patients can be handled completely or which patients need to be referred is in the hands of primary health facilities. Various challenges have been encountered in the effort to maximize the function of the gatekeeper in providing complete services, one of that is the limited availability of PPE and its use [20].

PPE supplies have been provided by each office in a region to be allocated for each health service. However, the problem is that its availability is not sufficient for the need which is certainly increasing every day. From the results of this study, it found that some doctors in primary care complained about the limited availability of PPE. Many of them have to spend personal funds to meet the need of PPE and some doctors even have to save on use of PPE. This is certainly caused discomfort among doctors who are struggling to provide services during a pandemic. In addition, some of the existing facilities and infrastructure in primary services are not supportive.

Barriers that occured in this study is similar with the barriers that occurred in previous studies regarding the limited supply of PPE. Emanuel et al said that since early 2020, US has experienced a severe shortage of the personal protective equipment (PPE) needed by health workers in order to fight against COVID-19 pandemic [21]. There are four possible factors that are being the main causes behind the limited supply of PPE. First, there is a large demand shock triggered by the need for the health care system and panic market behavior depletes PPE supplies. Second, the government failed to maintain and distribute domestic supplies. Last, major disruptions to the global PPE supply led to a sharp decrease in PPE supplies. Market and government failures make procurement of PPE by hospitals, health care providers, businesses, individuals and governments to be competitive and expensive in terms of time and money [22].

From previous studies, it was said that the main factor of the caused of structural weakness in the health care system was the wrong budget method used by the hospital. ${ }^{26}$ Based on a statement from the occupational safety and health administration (OSHA) organization, which obliges employers to provide PPE to health workers free of charge [23], [24]. The ideal PPE budgeting method would certainly align the interests of employers, healthcare workers and patients with the need for effective and efficient care facilities that are safe for all [25], [26]. 


\subsubsection{Barrierss and challenges based on individuals}

COVID-19 pandemic is a global threat that is currently being an attention in every country. The government's strict movement restrictions to reduce the spread of COVID-19 are likely having a negative impact on people's mental health [13], [27]. By this research, a pandemic situation as now becomes a burden to societ that gives the rise to psychological disorders in terms of both patients and health professionals. From the patients' point of view, they feel anxious about coming to a health check directly to a health service such as a clinic or health centers. This is because of the perspective of the society who is afraid to come and have a direct contact with health services because they feel that the risk of being exposed by COVID-19 is very large. In addition, there is a lot of information that is not known about its truth, which actually makes people being more depressed and stressed [28]. This is influenced by the low level of public education, so it is very easy to be influenced by the wrong information. The good knowledge, precise, valid can improve one's behaviour [29]-[31]. The role of a doctor here is needed so much in terms of education to provide more knowledge and improve the public mindset about the stigma of corona. However, if it is seen from a doctor's point of view, this certainly becomes a big burden and responsibility. In this case, doctors have to be more active in providing counseling or educating to society and be more objective so as not to be led by opinions from the uncertain information. In addition, doctors' responsibilities are also exacerbated by increasing of working hours in several health centers so that it is not only mental but also physical burden.

The results of the findings in this research are also in line with previous studies, that uncertainty health situation and its development and consequences can lead to mental disorders such as stress, excessive anxiety, and depression. Overall, these results highlight the enormous psychological impact of the COVID-19 pandemic on the population [29]-[32]. Besides, there are some opinions from previous research which suggests that frontline healthcare workers are generally vulnerable to the emotional impact of a pandemic situation. In this study, four manifestations of psychological distress were identified among health workers, namely fear, anxiety, frustration, and anger [16], [15], [33]. In this case, there are many factors triggered, for example, frustration is caused by the increasing working hour that makes doctors have to work longer than usual with more cases of disease handled.

The large number of COVID-19 incidents is accompanied by extensive information about this disease, but there is still a lot of disinformation and misinformation in the society which lead to excessive panic and refusal to follow government recommendations [29]. As on March 2020 to 6 April 2021, The Ministry of Communication and Informatics (Kemenkominfo) recorded 1,513 hoaxes spread on various social media platforms related to disinformation about the corona virus (COVID-19) [34]. The amount of information is supported by the development of the internet and the ease of access to information at this time. This circulating misinformation can affect people's knowledge, so that it can have an impact on people's behavior. The decisions and choices taken are mostly based on information from the internet, especially social media [29]. Therefore, the provision of knowledge provided by education is very useful in relation to complete unequal level of education among the society and a good communication strategy can help people prevent COVID-19 [26], [35]-[37].

\section{CONCLUSION}

The problems that are barriers and challenges faced by primary care physicians during the pandemic such as there was a decrease in the number of patient visits, inadequate health facilities, and the psychological condition of both doctors and patients becomes disturbed. It is necessary to provide specific, valid, and right-on-target knowledge in improving community behavior in efforts to prevent COVID-19 infection. In addition, the important role of the government to be more concerned about the future of health workers is needed.

\section{REFERENCES}

[1] Cucinotta D., Vanelli M. WHO declares COVID-19 a pandemic. Acta Bio Medica: Atenei Parmensis, 2020, 91.1: 157.

[2] Li H., Liu SM., Yu XH., Tang SL, and Tang CK., "Coronavirus disease 2019 (COVID-19): current status and future perspectives," International Journal of Antimicrobial Agents, vol. 55, no. 5, p. 105951, 2020.

[3] Lotfi M., Hamblin MR., and Rezaei N, "COVID-19: Transmission, prevention, and potential therapeutic opportunities," Clin Chim Acta, vol. 508, pp. 254-66, 2020, doi: 10.1016/j.cca.2020.05.04.

[4] The Task Force for the Acceleration of Handling COVID-19. Development of Positive Confirmed Cases of COVID-19 Per-Day, 2020. [Online]. Available: https://covid19.go.id/peta-sebaran

[5] Pettigrew L. M., De Maeseneer J., Anderson M. I. P., Essuman A., Kidd M. R., and Haines A., "Primary health care and the Sustainable Development Goals," The Lancet, vol. 386, 2119-2121, 2015.

[6] Zhijie X., Yuanqu Y., Yang W., Yi Q., Jianjiang P., Yiting L., and Lizheng F, "Primary Care Practitioners' Barrierss to and Experience of COVID-19 Epidemic Control in China: a Qualitative Study," Journal of General Internal Medicine, vol. 35, no. 11, pp. 3278-3284, 2020, doi: 10.1007/s11606-020-06107-3. 
[7] Coronavirus disease (COVID-19): resources for practitioners, "Helpful guidance for front-line workers responding to the COVID-19 pandemic," New York: United Nations Children's Fund; 2020. [Online]. Available: https://www.unicef.org/coronavirus/COVID-19-resources-practitioners

[8] Verbeek JH et al., "Personal protective equipment for preventing highly infectious diseases due to exposure to contaminated body fluids in healthcare staf," Cochrane Database of Systematic Reviews, no. 4, 2020, doi: 10.1002/14651858.CD011621.pub4.

[9] Jenifer C and Yana V, "Contributing factors to personal protective equipment shortages during the COVID-19 pandemic," Preventive Medicine, vol. 141, no. 2020, 2020, doi: 10.1016/j.ypmed.2020.106263.

[10] Zhijie X., Yuanqu Y., Yang W., Yi Q., Jianjiang P., Yiting L., and Lizheng F, "Primary Care Practitioners' Barrierss to and Experience of COVID-19 Epidemic Control in China: a Qualitative Study," Journal of General Internal Medicine, vol. 35, no. 11, pp. 3278-3284, 2020, doi: 10.1007/s11606-020-06107-3.

[11] Kunin M., Engelhard D., Piterman L., and Thomas S, "Response of general practitioners to infectious disease public health crises: an integrative systematic review of the literature," Disaster Med Public Health Prep, vol. 7, no. 5, pp. 522-533, 2013, doi: 10.1017/dmp.2013.82.

[12] Kisely S., Warren N., McMahon L., Dalais C., Henry I., Siskind D, "Occurrence, prevention, and management of the psychological effects of emerging virus outbreaks on healthcare workers: rapid review and metaanalysis," $B M J$, vol. 369, pp. 1-11, 2020, doi: 10.1136/bmj. m1642.

[13] Wang C et al., "Immediate psychological responses and associated factors during the initial stage of the 2019 coronavirus disease (COVID-19) epidemic among the general population in China," International Journal of Environmental Research and Public Health, vol. 17, no. 5, pp. 1-25, 2020.

[14] Li DKT and Zhu S, "Contributions and challenges of general practitioners in China fighting against the novel coronavirus crisis," Fam Med Com Health, vol. 8, no. 2, pp. 1-6, 2020, doi: 10.1136/fmch-2020- 000361.

[15] Lai J et al., "Factors Associated with Mental Health Outcomes among Health Care Workers Exposed to Coronavirus Disease 2019," JAMA Netw Open, vol. 3, no. 3, 2020, doi: 10.1001/jamanetworkopen. 2020.3976.

[16] Houghton C et al., "Barriers and facilitators to healthcare workers' adherence with infection prevention and control (IPC) guidelines for respiratory infectious diseases: a rapid qualitative evidence synthesis," Cochrane Database of Systematic Reviews, no. 4, 2020, doi: 10.1002/14651858.CD013582.

[17] Regulation of The Minister of Health Republic Indonesia Number 44 of 2016 about Public Health Center Management Guidelines. 1 September 2016. News of The Republic Of Indonesia Year 2016 Number 1423. Jakarta. 2016

[18] Susan, E, "Manajemen sumber daya manusia," Adaara: Jurnal Manajemen Pendidikan Islam, vol. 9, no. 2, pp. 952-962, 2019.

[19] Cahyadi, R. "Inovasi kualitas pelayanan publik pemerintah daerah," Fiat Justicia Jurnal Ilmu Hukum Fakultas Hukum Universitas Lampung, vol. 10, no. 3, pp. 569-586. 2016.

[20] Fitria K. W and Anhari A, "Analysis of the Characteristics and Perceptions of Service Users on the Utilization of Health centers as Gatekeepers in Two Bekasi City Health centers in 2016," Jurnal Ekonomi Kesehatan Indonesia 2016, vol. 2, no. 1, pp. 39-47, 2016.

[21] Emanuel EJ et al., "Fair Allocation of Scarce Medical Resources in the Time of COVID-19," New England Journal of Medicine, vol. 382, no. 21, pp. 2049-2055, 2020, doi: 10.1056/NEJMsb2005114.

[22] Jenifer $\mathrm{C}$ and Yana V, "Contributing factors to personal protective equipment shortages during the COVID-19 pandemic," Preventive Medicine, vol. 141, no. 2020, p. 106263, 2020, doi: https://doi.org/10.1016/j.ypmed.2020.106263.

[23] Barniv R., Danvers K., and Healy J., "The impact of medicare capital prospective payment regulation on hospital capital expenditures," Journal of Accounting and Public Policy, vol. 19, no. 1, pp. 9-40, 2000, doi: 10.1016/S02784254(99)00026-5.

[24] OSHA, "Employer Payment for Personal Protective Equipment; Final Rule," Retrieved from Washington, DC 2007. [Online]. Available: https://www.osha.gov/laws-regs/federalregister/ 2007-11-15-0

[25] Moses III, H., Matheson D.H.M., Dorsey E.R., George B.P., Sadoff D., and Yoshimura S., 2013. "The anatomy of health care in the United States," JAMA, vol. 310, no. 18, pp. 1947-1964, doi: https://doi.org/10.1001/jama.2013.281425.

[26] McLellan R.K., "Work, health, and worker well-being: roles and opportunities for employers," Health Aff., vol. 36 no. 2, pp. 206-213, 2017, doi: 10.1377/hlthaff.2016.1150.

[27] Qian Z and Xinping Z, "Inuence of workload, mental health and professional quality of life on healthcare workers' hand hygiene behavior in medical aid during COVID19 pandemic," Research Squere, pp, 1-15, 2020, doi: 10.21203/rs.3.rs-30058/v1.

[28] Rodríguez-Rey R., Garrido-Hernansaiz H., and Collado S., "Psychological Impact and Associated Factors During the Initial Stage of the Coronavirus (COVID-19) Pandemic Among the General Population in Spain," Front. Psychol., vol. 11, p. 1540, 2020, doi:10.3389/fpsyg.2020.01540

[29] Jesica M. and Rizma A. S, "Knowledge related to Coronavirus Disease (COVID-19) Prevention Efforts in Indonesia," HIGEIA, vol. 4, no. 3, pp. 333-346, 2020, doi: 10.15294/higeia/v4i3/37844.

[30] Fadilah M., Susanty M., Samsir, N. I., Trisa, Y., and Syakurah R. A, “The Influence ff Online Seminar on Public Knowledge in the Era of Pandemic COVID-19," Prosiding Applicable Innovation of Engineering and Science Research, 2020, pp. 280-284.

[31] Fadilah M., Aprilia S., and Syakurah R. A, "Evaluation of Public Obedience In Adapting New Habits Based On Health Belief Model," Prosiding Applicable Innovation of Engineering and Science Research, 2020, pp. 168-178. 
[32] Brooks S. K et al., "The psychological impact of quarantine and how to reduce it: rapid review of the evidence," The Lancet, vol. 395, no. 10227, pp. 912-920, 2020, doi: 10.1016/S0140-6736(20)30460-8.

[33] Kisely S., Warren N., McMahon L., Dalais C., Henry I., Siskind D., "Occurrence, prevention, and management of the psychological effects of emerging virus outbreaks on healthcare workers: rapid review and metaanalysis," BMJ, vol. 369, pp. 1-11, 2020, doi: 10.1136/bmj. m1642.

[34] Ministry of Communication and Informatics of the Republic of Indonesia (Kominfo RI), "Isu Hoaks COVID-19 rilis 6 april 2021 PKL 06.00 WIB Total:1513,” 2021. [Online]. Available: https://trustpositif.kominfo.go.id/assets/hoaks_covid/Total\%20Isu\%20Hoaks\%20COVID$19 \% 20$ sd\%2006\%20April\%202021.pdf

[35] Mahfuza N., Syakurah R. A., and Citra R, "Analysis and potential use of Google Trends as a monitoring tool for risk communication during COVID-19 pandemic," International Journal of Public Health, vol. 9, no. 4, pp. 399405, 2020, doi: 10.11591/ijphs.v9i4.20512.

[36] Amelia L. and Syakurah R. A, "Analysis of public search interest towards immune system improvement during the COVID-19 pandemic using google trends," International Journal of Public Health, vol. 9, no. 4, pp. 414-420, 2020, doi: 10.11591/ijphs.v9i4.20518.

[37] Chandra M., and Syakurah R, "Potential use of personal protection online search during COVID-19 pandemic for predicting and monitoring public," International Journal of Public Health, vol. 9, no. 4, 406-413, 2020, doi: 10.11591/ijphs.v9i4.20547.

\section{APPENDIX}

Table 1. Respondent characteristics

\begin{tabular}{|c|c|c|c|c|c|}
\hline Respondent & Gender & Age (year) & Origin & Practice place & Position \\
\hline N1 & Male & 53 & Ogan Komering Ilir & Clinic & General practitioners \\
\hline $\mathrm{N} 2$ & Female & 24 & Prabumulih & Health centers & Internship doctors \\
\hline N3 & Female & 35 & Teluk Betung & Health centers & General practitioners \\
\hline N4 & Male & 24 & Palembang & Health centers & Internship doctors \\
\hline N5 & Female & 32 & Palembang & Clinic & General practitioners \\
\hline N6 & Female & 38 & Bandung & Clinic & General practitioners \\
\hline N7 & Male & 24 & Palembang & Health centers & Internship doctors \\
\hline N8 & Female & 27 & Palembang & Health centers & General practitioners \\
\hline N9 & Female & 32 & Musi Banyuasin & Health centers & General practitioners \\
\hline N10 & Female & 25 & Cianjur & Health centers & General practitioners \\
\hline N11 & Female & 24 & Bengkulu & Health centers & Internship doctors \\
\hline $\mathrm{N} 12$ & Female & 27 & Muara Enim & Health centers & General practitioners \\
\hline N13 & Male & 35 & Musi Rawas & Health centers & General practitioners \\
\hline N14 & Male & 25 & Jakarta & Clinic & General practitioners \\
\hline N15 & Female & 24 & Maluku & Health centers & Internship doctors \\
\hline N16 & Female & 24 & Palembang & Health centers & Internship doctors \\
\hline N17 & Female & 40 & Palembang & Health centers & General practitioners \\
\hline N18 & Female & 32 & Palembang & Health centers & General practitioners \\
\hline N19 & Male & 27 & Bangka Belitung & Health centers & General practitioners \\
\hline $\mathrm{N} 20$ & Male & 59 & Palembang & Health centers & Heads of Health centers \\
\hline $\mathrm{N} 21$ & Male & 30 & Palembang & Health centers & General practitioners \\
\hline $\mathrm{N} 22$ & Female & 28 & Palembang & Clinic & General practitioners \\
\hline $\mathrm{N} 23$ & Female & 25 & Palembang & Health centers & General practitioners \\
\hline $\mathrm{N} 24$ & Female & 27 & Sulawesi & Health centers & General practitioners \\
\hline $\mathrm{N} 25$ & Male & 45 & Palembang & Clinic & General practitioners \\
\hline $\mathrm{N} 26$ & Male & 27 & Padang & Health centers & General practitioners \\
\hline $\mathrm{N} 27$ & Male & 26 & Gorontalo & Health centers & Temporary Doctors (Pegawai Tidak Tetap-PTT) \\
\hline $\mathrm{N} 28$ & Female & 23 & Palembang & Health centers & Internship doctors \\
\hline $\mathrm{N} 29$ & Male & 32 & Bangka Belitung & Health centers & Heads of Health centers \\
\hline $\mathrm{N} 30$ & Male & 24 & Muara Enim & Health centers & Internship doctors \\
\hline N31 & Female & 34 & Karawang & Clinic & General practitioners \\
\hline N32 & Male & 56 & Palembang & Health centers & General practitioners \\
\hline $\mathrm{N} 33$ & Female & 50 & Palembang & Health centers & General practitioners \\
\hline N34 & Male & 30 & Jawa Tengah & Clinic & General practitioners \\
\hline N35 & Male & 24 & Palembang & Clinic & Internship doctors \\
\hline N36 & Female & 46 & Jambi & Clinic & General practitioners \\
\hline N37 & Female & 24 & Palembang & Clinic & Internship doctors \\
\hline N38 & Female & 25 & Palembang & Clinic & Internship doctors \\
\hline N39 & Female & 23 & Palembang & Health centers & Internship doctors \\
\hline $\mathrm{N} 40$ & Male & 24 & Palembang & Health centers & Internship doctors \\
\hline N41 & Female & 25 & Palembang & Health centers & Internship doctors \\
\hline $\mathrm{N} 42$ & Female & 33 & Palembang & Health centers & General practitioners \\
\hline N43 & Female & 24 & Palembang & Health centers & Internship doctors \\
\hline N44 & Female & 27 & Palembang & Health centers & General practitioners \\
\hline
\end{tabular}


Table 4. Results of interviews related to barrierss and challenges based on individuals

\begin{tabular}{l}
\hline Themes \\
\hline \\
The psychological state and attitude of \\
the patient in response to a pandemic
\end{tabular}

The level of education and the economy of the community that affects patient knowledge about COVID-19

The mental condition of doctors in giving services during the COVID-19 pandemic Interpretations

Attitudes of patients in responding the COVID-19 pandemic situation [13]

1. Some patients are dishonest and less open in conveying information related to complaints and travel history, making it difficult for doctors to detect their disease

2. Patients lack discipline and adherence to health protocols is decreasing over time

3. The patient's level of awareness is still low in responding to the COVID-19 pandemic situation

4. Some patients do not believe the truth about the COVID-19 pandemic situation so they do not want to apply health protocols.

Patients experience excessive fear and anxiety in the face of a COVID-19 pandemic situation [7]

1. Patients feel afraid to come for having treatment directly at the health centers because they think they are afraid of contracting corona

2. Patients deliberately go to a lower health facility with the expectation that the risk of exposure to COVID-19 is low

3. Some patients experience psychosomatics due to excessive fear and anxiety

Low levels of education and the economy are indicators of barrierss to consultation and education during the COVID-19 pandemic [7]

1. Internet that is difficult to access by people with low educational and economic level.

2. Difficulty in education related to low patient knowledge.

3. Patients with middle and lower education level and the economy tend not to believe in the COVID-19 pandemic situation.

4. Low level of knowledge makes people very easily affected by hoaxes which are currently widely spread among the community.

Large burdens and responsibilities that make doctors feel anxious and stressed out [15]

1. Counseling and education must be intensively carried out by a doctor.

2. During this pandemic, there were many hoax news circulating among the public. Therefore, before doctors provide counseling or education, the information to be conveyed must be based on valid sources.

3. In serving patients in pandemic situations, a very heavy burden is felt by doctors, both in physically and mentally.

4. Doctors must learn to expand knowledge related to COVID-19.

5. Doctors are very worried and must be vigilant in handling patients who are less disciplined in complying with health protocols.

6. Doctors must be more objective so as not to be led by public opinion 